\section{Assessment of Pruning and Controlled-release Fertilizer to Rejuvenate Huanglongbing- affected Sweet Orange}

\author{
Tripti Vashisth ${ }^{1}$ and Taylor Livingston ${ }^{1}$
}

ADDITIONAL INDEX WORDs. citrus greening, leaf area index, nutrition, root-to-shoot ratio

\begin{abstract}
Summary. Previous research has shown that Huanglongbing \{HLB [causal agent Candidatus Liberibacter asiaticus (CLas)]\}-affected sweet orange (Citrus sinensis) trees have a reduced root-to-shoot ratio, potentially due to the high rate of root death. The diminished root system cannot support the existing aboveground canopy and a cycle of imbalance begins. As a result, the tree enters into a continuous carbohydrate stress cycle and, eventually, the tree declines. Therefore, the goal of this study was to evaluate pruning as a strategy to adjust the root-to-shoot ratio to improve growth and productivity of HLB-affected trees. In Jan. 2015, a 3-year trial was initiated on a 14-yearold grove of 'Hamlin' sweet orange on Swingle citrumelo (Citrus paradisi $\times$ Poncirus trifoliate) rootstock that was symptomatic of HLB and produced less than $180 \mathrm{lb}$ of fruit per tree. The four pruning treatments were as follows: 1 ) $0 \%$ pruning (no canopy removal), 2) 25\% pruning (canopy removed), 3) 50\% pruning (canopy removed), and 4 ) $\mathbf{8 0 \%}$ pruning (canopy removed). In a split-plot design, two sources of fertilizer were evaluated in combination with the pruning: 1 ) conventional fertilizer [CNV (dry granular)] applied at $200 \mathrm{lb} /$ acre nitrogen (N) in five split applications per year, and 2) controlled-release fertilizer (CRF) applied at $150 \mathrm{lb} /$ acre $\mathrm{N}$, split in three applications per year. Within each pruning treatment, half of the trees received $\mathrm{CNV}$ and the other half received CRF. The fertilizer treatments were applied in each of the 3 years; however, pruning was performed only once in the beginning of the experiment. The trees that were pruned produced new vegetative growth that looked healthy with no visual HLB symptoms (initially); however, the trees remained positive for CLas throughout the study as determined by quantitative real-time polymerase chain reaction. The $\mathbf{8 0 \%}$ pruned trees grew vigorously over the course of 3 years but remained significantly smaller in canopy than control trees ( $0 \%$ pruning) for both CRF and CNV treatments. The $25 \%$ and $50 \%$ pruned tree canopies grew back and were similar in canopy size as $0 \%$ pruning (control) treatment by the end of year 2. At the end of the study, the use of CRF on $25 \%$ pruned trees resulted in a significantly higher leaf area index as compared with trees receiving CNV. A significant positive linear correlation was observed between canopy volume and root density; the root density decreased with intensive pruning. A significant positive correlation was also observed between canopy volume and yield, and a negative correlation between canopy volume and fruit drop. There were no significant increases in yield resulting from any pruning or fertilization treatments compared with controls ( $0 \%$ pruning). However, with the use of $\mathrm{CRF}$, the amount of $\mathrm{N}$ and frequency of application were reduced. Overall, our results indicate that pruning did not improve the productivity of HLB-affected trees over the course of 3 years. Therefore, severe pruning is not a viable option to rejuvenate the HLB-affected trees.
\end{abstract}

$\mathrm{H}$

$\mathrm{LB}$ is one of the most devastating diseases of citrus (Citrus sp.) and threatens citrus

Received for publication 11 Apr. 2019. Accepted for publication 20 Sept. 2019

Published online 29 October 2019

${ }^{1}$ Citrus Research and Education Center, University of Florida/ Institute of Food and Agricultural Sciences, 700 Experiment Station Road, Lake Alfred, FL 33850

We thank Troy Gainey, Ward Gunter, and ICL Fertilizer for helping with this research.

T.V. is the corresponding author. E-mail: tvashisth@ ufl.edu.

This is an open access article distributed under the CC BY-NC-ND license (https://creativecommons.org/ licenses/by-nc-nd/4.0/).

https://doi.org/10.21273/HORTTECH04382-19 production wherever it is present (Bové, 2006). HLB is caused by Candidatus Liberibacter asiaticus (CLas) and is spread by an insect vector, the asian citrus psyllid [Diaphorina citri (Halbert and Manjunath,
2004)]. CLas, is a phloem-limited bacterium; and once a tree is infected by CLas, plugging in the phloem sieve pores can be observed, resulting in an accumulation of starch in symptomatic leaves and the aerial stem (Etxeberria et al., 2009; Kim et al., 2009; Schneider, 1968). Visible symptoms of HLB-affected trees include yellowing of leaves, blotchy mottle and/or chlorotic patterns of leaves resembling those induced by zinc and iron deficiencies, and small upright leaves (Bové, 2006). In HLB-affected trees, the disruption of vascular function, loss of roots, and altered mineral nutrition leads to arrested plant and fruit growth and decline in production (Bové, 2006; Halbert and Manjunath, 2004). Fruit produced in severely affected trees are often smaller, lopsided, poorly colored, with aborted seeds, and abscise/drop prematurely, eventually leading to decline in yield and economical losses for the growers (Bassanezi et al., 2011).

All citrus varieties are vulnerable to HLB, and because there is no cure, all of the existing groves and new plantings are susceptible to HLB. In the past decade, Florida's orange production dropped from 170 million boxes $(90 \mathrm{lb} / \mathrm{box})$ in the $2007-08$ season to $\approx 45$ million boxes in the 2017-18 season (U.S. Department of Agriculture, 2018). In such conditions, vector control and intensive fertilization and irrigation are the two primary strategies adopted by Florida growers (Vashisth and Vincent, 2018). Florida citrus growers are desperately looking for a solution to HLB to improve tree health and productivity as well as keep the production cost as low as possible.

Early in the infection, HLBaffected trees suffer a significant root loss (Graham et al., 2013), and the CLas presence can be detected in the root system before the appearance of visible symptoms on the tree (Johnson et al., 2014). This potentially causes an

\begin{tabular}{llll}
\hline $\begin{array}{l}\text { Units } \\
\begin{array}{l}\text { To convert U.S. to SI, } \\
\text { multiply by }\end{array}\end{array}$ & U.S. unit & SI unit & $\begin{array}{l}\text { To convert SI to U.S., } \\
\text { multiply by }\end{array}$ \\
\hline 0.3048 & $\mathrm{ft}$ & $\mathrm{m}$ & 3.2808 \\
0.0283 & $\mathrm{ft}^{3}$ & $\mathrm{~m}^{3}$ & 35.3147 \\
2.54 & inch $(\mathrm{es})$ & $\mathrm{cm}$ & 0.3937 \\
0.4536 & $\mathrm{lb}$ & $\mathrm{kg}$ & 2.2046 \\
1.1209 & $\mathrm{lb} / \mathrm{acre}$ & $\mathrm{kg} \cdot \mathrm{ha}^{-1}$ & 0.8922 \\
1.0012 & $\mathrm{oz} / \mathrm{ft}^{3}$ & $\mathrm{mg} \cdot \mathrm{cm}^{-3}$ & 0.9988 \\
$\left({ }^{\circ} \mathrm{F}-32\right) \div 1.8$ & $\mathrm{o} F$ & ${ }^{\circ} \mathrm{C}$ & $\left({ }^{\circ} \mathrm{C} \times 1.8\right)+32$
\end{tabular}




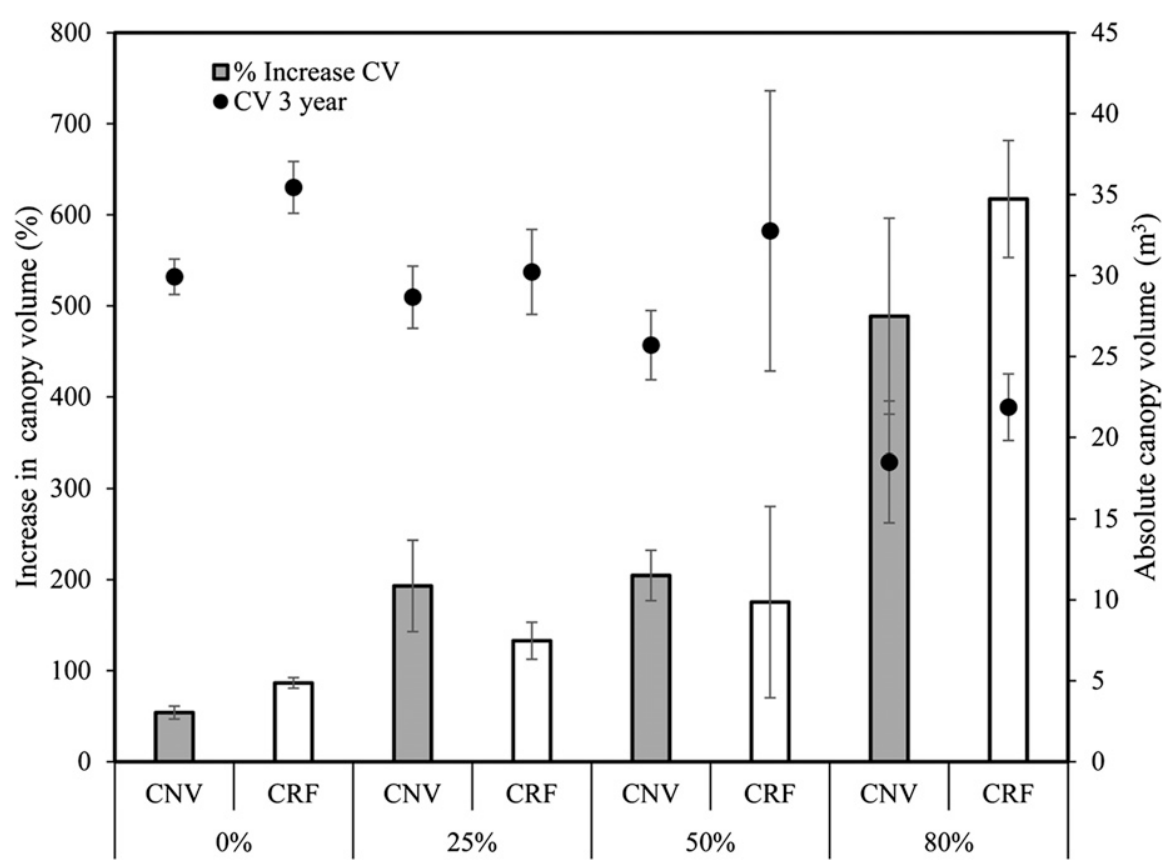

Fig. 1. Average canopy volume [CV (black dots)] and percentage increase (since Jan. 2015-17) in CV (gray- and white-fill bars) at the end of experiment in Huanglongbing-affected 'Hamlin' sweet orange on Swingle citrumelo rootstock. The pruning was performed in Jan. 2015. The pruning treatments were as follows: 1) $0 \%$, no canopy removal (control treatment) tree height $\approx 12 \mathrm{ft}(3.65 \mathrm{~m}) ; 2) 25 \%$ reduction, canopy topped $\approx 9 \mathrm{ft}(2.74 \mathrm{~m}) ; 3) 50 \%$ reduction, canopy topped $\approx 6 \mathrm{ft}$ $(1.82 \mathrm{~m})$; and 4$) 80 \%$ reduction, canopy topped at $6 \mathrm{ft}$ and all the major branches were manually cut back (buck horned). The fertilizer treatments were as follows: 1) conventional fertilizer (CNV) applied at $200 \mathrm{lb} /$ acre $\left(224.17 \mathrm{~kg} \cdot \mathrm{ha}^{-1}\right)$ nitrogen $(\mathrm{N})$ in five split applications per year, and 2) controlled-release fertilizer $(C R F)$ applied at $150 \mathrm{lb} /$ acre $\left(168.13 \mathrm{~kg} \cdot \mathrm{ha}^{-1}\right) \mathrm{N}$ split in three applications per year. Error bars $= \pm S D ; 1 \mathrm{~m}^{3}=35.3147 \mathrm{ft}^{3}$.

imbalance between the root and shoot system and reduces the root-to-shoot ratio as compared with healthy plants. Consequently, the water and nutrient uptake is impeded (Kadyampakeni et al., 2014), the debilitated root system cannot support the existing aboveground canopy and fruit production, and, as a result, the tree health declines. Therefore, pruning to adjust the root-to-shoot ratio seems like a logical and rational choice. Nevertheless, Rouse et al. (2017) reported that severe ("buck horn") pruning of HLB-affected trees did not result in tree health or yield improvement over a period of 5 years, whereas enhanced foliar nutritional treatment had an effect on yield but was not economically profitable. Overall, they speculated that a moderate pruning treatment might be beneficial for improving health and productivity of HLB-affected trees. On the other hand, many field research/observations suggest that the use of a constant and balanced irrigation and nutrition program (soil as well as foliar-applied) can improve the health and productivity of HLBaffected trees (Morgan et al., 2016; Schumann et al., 2012; Spann and Schumann, 2009). Recently, the use of CRF for new citrus plantings grown under HLB-prevalent conditions has been shown to be promising in improving growth and productivity (Vashisth and Grosser, 2018). Many growers in Florida have considered using CRF for HLB-affected trees; however, because of limited scientific literature on the use of CRF in mature HLB-affected trees and the high cost of CRF, its use has been limited. Therefore, the objective of this study was to evaluate different levels of pruning with the use of CRF to rehabilitate HLB-affected mature bearing trees.

\section{Materials and methods}

Plant MATERIAL AND EXPERIMENTAL DESIGN. Fourteen-year-old 'Hamlin' orange trees on Swingle citrumelo rootstock, $\approx 12 \mathrm{ft}$ in height, growing at an experimental grove at the University of Florida Citrus Research and Education Center in Lake Alfred, FL, were used in this experiment. Trees were regularly irrigated (via microsprinklers) and grown under standard commercial grove management practices, which included regular insect and disease control. The site was on the Mid-Florida Ridge and soil $\mathrm{pH}$ of the grove was identified in the ideal range, ranging from 6.5 to 7.2 ; therefore, no adjustments were made to alter soil or irrigation water $\mathrm{pH}$. All of the trees in the plot showed symptoms for HLB and were confirmed positive for CLas. The experiment was set up as a completely randomized design with split-plot $(n=5)$, with pruning treatments as main plot and fertilizer treatments as subplots. Data were collected on at least six random trees within each subplot; the data trees were selected pretreatment based on their uniformity in canopy density and volume. The trees were monitored for 3 consecutive years $(2015,2016$, and 2017).

Pruning treatments. The pruning treatments were performed once in Jan. 2015 using a commercial mechanical topper (only the top of the canopy was removed). The pruning treatments $(\mathrm{Pr})$ were as follows: 1$)$ $0 \%$, no canopy removal (control treatment); 2) $25 \%$ reduction, canopy topped about at $9 \mathrm{ft}$; 3) $50 \%$ reduction, canopy topped at $\approx 6 \mathrm{ft}$; and 4 ) $80 \%$ reduction, canopy topped at $\approx 6$ $\mathrm{ft}$ and all the major branches were manually cut back ("buck horned").

Fertilizer treatments. The trees were fertilized according to standard University of Florida, Institute of Food and Agricultural Sciences (UF IFAS) guidelines for citrus fertilization (Obreza and Morgan, 2008); no special adjustments were made for HLBaffected trees (as there were no reports stating beneficial effects of high dose of micronutrients on HLB-affected trees when this experiment started). The two soil-applied fertilizer (F) treatments evaluated were $\mathrm{CNV}$ and CRF. Both CNV and CRF were similar in analysis for all macronutrients and micronutrients applied, except for the applied rate of nitrogen. The $\mathrm{N}$ in $\mathrm{CNV}$ was $200 \mathrm{lb} /$ acre and the CRF was applied at a $25 \%$ lower rate than CNV (150 lb/acre in years 2 and 3 


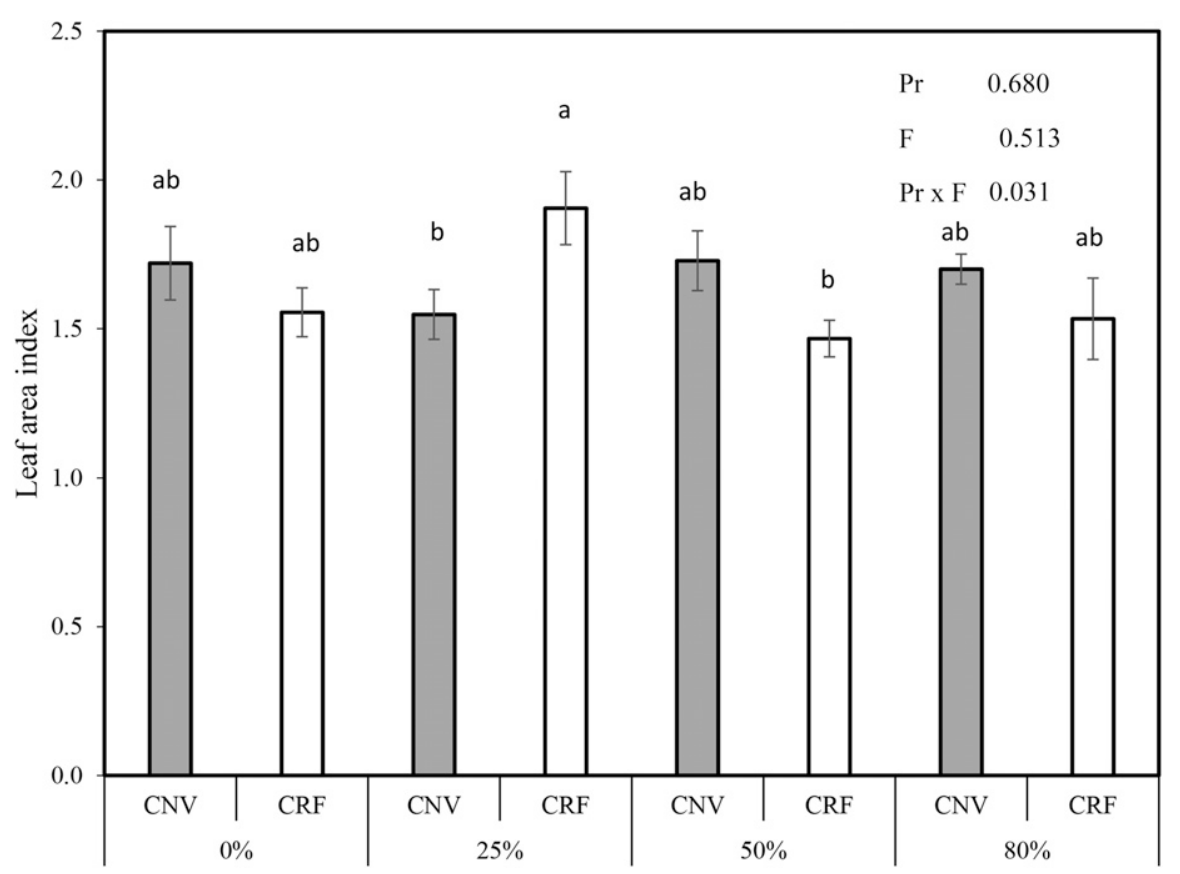

Fig. 2. Average leaf area index at the end of experiment with probability values in Huanglongbing-affected 'Hamlin' sweet orange on Swingle citrumelo rootstock. The pruning was performed in Jan. 2015. The pruning treatments $(\mathrm{Pr})$ were as follows: 1) $0 \%$, no canopy removal (control treatment) tree height $\approx 12 \mathrm{ft}$ $(3.65 \mathrm{~m}) ; 2) 25 \%$ reduction, canopy topped $\approx 9 \mathrm{ft}(2.74 \mathrm{~m}) ; 3) 50 \%$ reduction, canopy topped $\approx 6 \mathrm{ft}(1.82 \mathrm{~m})$; and 4$) 80 \%$ reduction, canopy topped at $6 \mathrm{ft}$ and all the major branches were manually cut back (buck horned). The fertilizer treatments (F) were as follows: 1) conventional fertilizer (CNV) applied at 200 lb/acre $\left(224.17 \mathrm{~kg} \cdot \mathrm{ha}^{-1}\right)$ nitrogen $(\mathrm{N})$ in five split applications per year, and 2) controlled-release fertilizer (CRF) applied at $150 \mathrm{lb} /$ acre $\left(168.13 \mathrm{~kg} \cdot \mathrm{ha}^{-1}\right) \mathrm{N}$ split in three applications per year. Error bars $= \pm S D$; bars not assigned the same letter indicate statistically significant differences among $\operatorname{Pr} \times \mathrm{F}$ treatment using Tukey's honestly significance difference test at $\alpha=0.05$.

and $130 \mathrm{lb} /$ acre was applied in the first year). The lower rate of $\mathrm{N}$ in the case of CRF was based on literature and the fact that the CRF is less likely to leach from soil; therefore, a lesser rate will be sufficient. Both CNV and CRF contained urea as a primary source of $\mathrm{N}$; however, the urea was polymer-coated in the CRF. The CNV was split in five applications (March, May, July, September, and October) per year and CRF was split in three applications (March, July, and October) per year. All of the trees in the experiment (both $\mathrm{CRF}$ and $\mathrm{CNV}$ ) received the same foliar-applied nutrients.

CLas Detection. CLas detection was done at pretreatment, 3 months, and 6 months after pruning. The midribs of the mature fully expanded leaves were excised and stored at $-80^{\circ} \mathrm{C}$ until DNA extraction. DNA extraction was performed using DNeasy Plant Kits (Qiagen, Valencia, CA) and quantitative real-time polymerase chain reaction was performed according to $\mathrm{Li}$ et al. (2006) using $r p o B$ (Ananthakrishnan et al., 2013; Forward-TGAGGAGAAACGATGGCAAAAGGC, Reverse-GACATACCTGATCTCATTGAAGTTCAG, probe: TTGTGTTCAATGGTCTCGGGCG). The results of CLas detection are reported as cycle threshold $(\mathrm{Ct})$ value.

Canopy volume measurement. Canopy volume was measured at pretreatment, 3 and 6 months posttreatment, then annually, and after harvest. Canopy volume, expressed as cubic meters was calculated using a geometric prolate spheroid formula:

$$
\left[(4 / 3)(\pi)(H / 2)(A C R)^{2}\right],
$$

where $\pi=3.14, \mathrm{H}=$ tree height, and $\mathrm{ACR}=$ average canopy radius. ACR was calculated by dividing tree diameter by 2 and calculating average radius. Tree diameter was measured in two directions: east to west (Dl) and north to south (D2). Percentage increase in canopy volume was calculated as the increase in canopy volume from the time of pruning and at the end of the experiment.

Canopy density. HLB-affected trees often have sparse canopies; therefore, canopy density can be a good indicator of tree health and growth. Leaf area index (LAI) was measured for each tree to estimate canopy density. A plant canopy imager (CI-110; CID Bio-Science, Camas, WA) was used to measure the LAI and all the measurements were taken in the morning of a sunny day at the center of the canopy. The instrument was equipped with numerous light sensors to measure photosynthetically active radiation and with a global positioning unit to calculate the zenith angle for an accurate measurement of LAI. LAI was measured only at the end of the experiment to assess total growth of the tree.

Root DENSITY. Root density was measured at the end of the experiment (after harvest of 2017) from at least three trees per subplot. From each tree, eight evenly spaced soil cores, $\approx 1 \mathrm{~m}$ from the trunk of the tree, were taken from the wetted zone. Roots were sifted, washed, and dried in an oven at $50{ }^{\circ} \mathrm{C}$ for 48 $h$, then the dry weight of the root samples was obtained. Root density was expressed as milligram of dry weight per cubic centimeter of soil.

LEAF NUTRIENT ANALYSIS. Thirty random leaves with intact petioles per block were collected annually from nonfruiting branches. The collected leaves were washed using acidic soap, then the leaves were dried for $48 \mathrm{~h}$ in a convection oven (Thermo Fisher Scientific, Waltham, MA) and ground to a fine powder. Ground leaves were sent to Waters Agricultural Laboratories (Camilla, GA) to perform a standard leaf nutrient analysis.

Preharvest fruit Drop, yield, AND Quality. Preharvest fruit drop was monitored each year and measured from $\approx 3$ months before (September) until harvest (December). Preharvest fruit drop, expressed as a percentage, was calculated by counting the number of fruit that dropped from the trees every 15 $\mathrm{d}$ and considering the total number of fruit that were taken off the tree at harvest. When the total soluble 


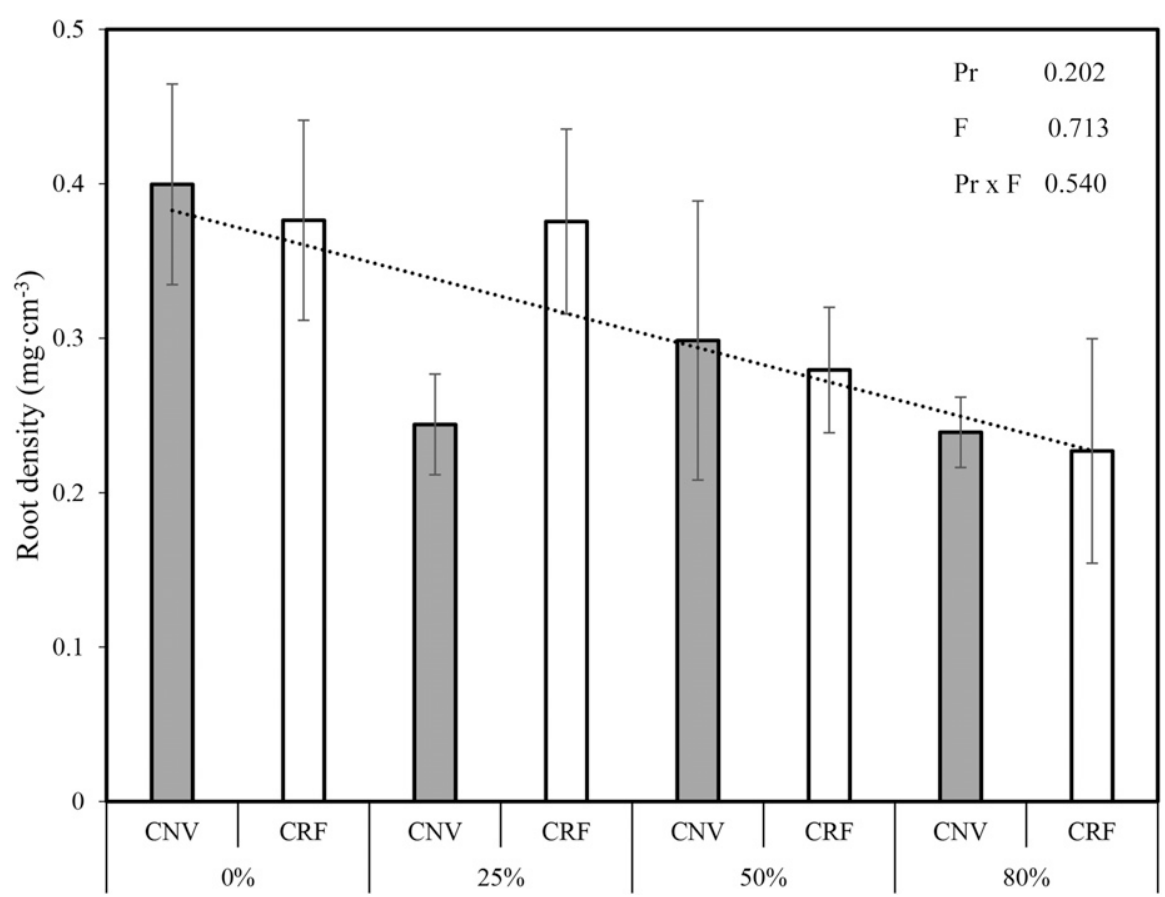

Fig. 3. Average root density at the end of experiment with probability values in Huanglongbing-affected 'Hamlin' sweet orange on Swingle citrumelo rootstock. The pruning was performed in Jan. 2015. The pruning treatments ( $\mathrm{Pr}$ ) were as follows: 1) $0 \%$, no canopy removal (control treatment) tree height $\approx 12 \mathrm{ft}$ $(3.65 \mathrm{~m}) ; 2) 25 \%$ reduction, canopy topped $\approx 9 \mathrm{ft}(2.74 \mathrm{~m}) ; 3) 50 \%$ reduction, canopy topped at $\approx 6 \mathrm{ft}(1.82 \mathrm{~m})$; and 4$) 80 \%$ reduction, canopy topped $6 \mathrm{ft}$ and all the major branches were manually cut back (buck horned). The fertilizer treatments (F) were as follows: 1 ) conventional fertilizer (CNV) applied at 200 $\mathrm{lb} /$ acre $\left(224.17 \mathrm{~kg} \cdot \mathrm{ha}^{-1}\right)$ nitrogen $(\mathrm{N})$ in five split applications per year and 2$)$ controlled-release fertilizer (CRF) applied at $150 \mathrm{lb} /$ acre $\left(168.13 \mathrm{~kg} \cdot \mathrm{ha}^{-1}\right) \mathrm{N}$ split in three applications per year. The dotted lines show the significant inverse correlation between pruning intensity, and root density was observed. Error bars = $\pm \mathrm{SD} ; 1 \mathrm{mg} \cdot \mathrm{cm}^{-3}=0.9988 \mathrm{oz} / \mathrm{ft}^{3}$.

solids to titratable acidity ratio of fruit reached commercial harvest standards, the fruit were hand harvested by commercially trained harvesters. Fruit yield is expressed as total pounds of fruit per tree. A sample of 20 fruit per data tree was taken for fruit size, and the size was measured using a handheld digital caliper to measure the equatorial length on all 20 fruit. After fruit size measurement, the 20 fruit were squeezed for juice extraction for soluble solids analysis on pooled juice. Pooled juice soluble solids was measured using a handheld refractometer (Atago Co., Tokyo, Japan) and are expressed as percentage.

Statistical anALYSIs. All statistical analyses were performed for each year individually, using two-way analysis of variance (ANOVA) at $\alpha=0.05$ using SigmaPlot (version 11; Systat Software, San Jose, CA). Pr and F were considered the two factors and different measured parameters were the responses. Mean separation was performed using Tukey's honestly significance difference test at $P=$ 0.05 . When there was significant $\operatorname{Pr} \times$ $F$ interactions, the mean separation was performed between all treatment combinations (four pruning treatments with two fertilizer types); when $\operatorname{Pr} \times \mathrm{F}$ interaction and $\mathrm{F}$ effect was not significant and main effect of $\operatorname{Pr}$ was statistically significant, the means were compared between pruning treatments. Linear regression analysis was performed to assess relationship among canopy volume, root density, and fruit drop.

\section{Results}

CLas. All the trees used in this experiment were positive for CLas (data not shown), where Ct ranged from 24 to 33 at pretreatment. The new flush was detected to be CLas positive at 3 and 6 months posttreatment, suggesting no effect of pruning or fertilizer on CLas. The range of Ct remained similar with no significant change; no significant differences were observed among the treatments.

Canopy volume. As expected, high pruning treatments resulted in significant canopy reduction; nevertheless, within 3 months after pruning, significant visual growth was observed in all of the pruned trees. At 3 months posttreatment, no significant interaction was observed between pruning treatment and fertilizer applied $(P=0.098)$. Altogether, CRF trees showed a more pronounced increase in canopy $(P=$ $0.018)$ as compared with $\mathrm{CNV}$ trees. Overall, control treatment ( $0 \%$ pruning) had the largest canopy, followed by $25 \%, 50 \%$, and $80 \%$ pruned trees $(P<0.001)$. From Fall 2015 (6 months posttreatment) until the end of the experiment, there was no significant interaction observed between pruning treatment and fertilizer $(P>$ $0.05)$. At the end of the experiment, CRF and CNV treatments were not statistically different $(P=0.072)$; however, the canopy volume of trees receiving CRF was numerically higher. The most severe pruning treatment, $80 \%$, had a significantly smaller canopy compared with $0 \%$ and $25 \%$ pruning treatment $(P=$ $0.007)$. However, $0 \%, 25 \%$, and $50 \%$ pruning treatments had similar canopy volume at the end of the experiment. When considering percentage increase in canopy volume over the course of the experiment, there was no significant $\operatorname{Pr} \times \mathrm{F}$ interaction $(P=$ $0.288)$ or effect of fertilizer $(P=$ $0.666)$. Figure 1 shows the canopy volume at the end of the experiment and percentage increase in canopy volume over 3 years since the time of pruning. Eighty percent pruning treatment showed significantly higher percentage increase in canopy volume compared with $0 \%, 25 \%$, and $50 \%$ pruning treatments $(P<0.001)$. The percentage increase in canopy volume of $50 \%$ pruning treatment was higher than $0 \%(P=0.039)$, whereas $0 \%$ and $25 \%$ pruning treatments were not significantly different from each other.

LAI. The LAI is shown in Fig. 2. A significant $\operatorname{Pr} \times \mathrm{F}$ interaction was observed in LAI $(P=0.031)$. The $25 \%$ pruning treatment with CRF showed 
Table 1. Average preharvest fruit drop and yield per tree with probability values in Huanglongbing-affected 'Hamlin' sweet orange on Swingle citrumelo rootstock. The pruning was performed in Jan. 2015. The pruning treatments (Pr) were as follows: 1 ) $0 \%$, no canopy removal (control treatment) tree height $\approx 12 \mathrm{ft}(3.66 \mathrm{~m}) ; 2) 25 \%$ reduction, canopy topped $\approx 9 \mathrm{ft}(2.74 \mathrm{~m}) ; 3) 50 \%$ reduction, canopy topped $\approx 6 \mathrm{ft}(1.83 \mathrm{~m})$; and 4$) 80 \%$ reduction, canopy topped at $6 \mathrm{ft}$ and all the major branches were manually cut back (buck horned). The fertilizer treatments (F) were as follows: 1 ) conventional fertilizer (CNV) applied at $200 \mathrm{lb} /$ acre $\left(224.17 \mathrm{~kg} \cdot \mathrm{ha}^{-1}\right)$ nitrogen $(\mathrm{N})$ in five split applications per year, and 2) controlled-release fertilizer (CRF) applied at $150 \mathrm{lb} /$ acre (168.13 $\left.\mathrm{kg} \cdot \mathrm{ha}^{-1}\right) \mathrm{N}$ split in three applications per year.

\begin{tabular}{|c|c|c|c|c|c|c|c|}
\hline \multirow[b]{2}{*}{$\operatorname{Pr}(\%)$} & \multirow[b]{2}{*}{ F } & \multicolumn{3}{|c|}{ Fruit drop (\%) } & \multicolumn{3}{|c|}{ Yield $(\mathrm{lb} / \text { tree })^{\mathrm{z}}$} \\
\hline & & 2015 & 2016 & 2017 & 2015 & 2016 & 2017 \\
\hline \multirow[t]{2}{*}{0} & $\mathrm{CNV}$ & $32 b^{y}$ & $13 \mathrm{~b}$ & 52 & $105 \mathrm{a}$ & $190 \mathrm{a}$ & 129 \\
\hline & $\mathrm{CRF}$ & 43 & 23 & 37 & 74 & 140 & 142 \\
\hline \multirow[t]{2}{*}{25} & $\mathrm{CNV}$ & $78 \mathrm{a}$ & $19 \mathrm{~b}$ & 40 & $33 \mathrm{~b}$ & $157 \mathrm{ab}$ & 110 \\
\hline & CRF & 66 & 17 & 42 & 30 & 174 & 129 \\
\hline \multirow[t]{2}{*}{50} & $\mathrm{CNV}$ & $85 \mathrm{a}$ & $23 \mathrm{a}$ & 36 & $10 \mathrm{c}$ & $113 \mathrm{bc}$ & 75 \\
\hline & $\mathrm{CRF}$ & 87 & 16 & 44 & 11 & 140 & 88 \\
\hline \multirow[t]{2}{*}{80} & $\mathrm{CNV}$ & $52 \mathrm{~b}$ & $25 \mathrm{a}$ & 44 & $7 \mathrm{c}$ & $96 \mathrm{c}$ & 107 \\
\hline & CRF & 33 & 31 & 38 & 24 & 108 & 112 \\
\hline $\operatorname{Pr}$ & & $<0.001$ & 0.032 & 0.850 & $<0.001$ & 0.022 & 0.084 \\
\hline $\mathrm{F}$ & & 0.482 & 0.527 & 0.505 & 0.792 & 0.944 & 0.383 \\
\hline $\operatorname{Pr} \times F$ & & 0.342 & 0.149 & 0.196 & 0.622 & 0.337 & 0.990 \\
\hline
\end{tabular}

${ }^{\mathrm{z}} 1 \mathrm{lb}=0.4536 \mathrm{~kg}$.

${ }^{y}$ Means not followed by the same letters are statistically significantly different among $\operatorname{Pr}$ within that year, given that there were no interaction effects of $\operatorname{Pr}$ and F and F effect, using Tukey's honestly significance difference test at $\alpha=$ 0.05 .

significantly higher LAI as compared with $25 \%$ pruning treatment with $\mathrm{CNV}$. Overall, the LAI ranged from 1.47 to 1.9 , where $25 \%$ pruning treatment with CRF had the highest average LAI (1.905).

Root DENSITY. Root density measured at the end of the experiment is shown in Fig. 3. All of the trees analyzed had very low root density compared with historical data of healthy trees, where the average root density was $1.7 \mathrm{mg} \cdot \mathrm{cm}^{-3}$ (Graham, 1995; Graham et al., 2013). The mean root density ranged from 0.23 to $0.40 \mathrm{mg} \cdot \mathrm{cm}^{-3}$. With ANOVA analysis, no significant differences were observed among pruning treatment, fertilizer treatment, or interaction. However, a significant linear regression $\left(R^{2}=0.61, P=0.032\right)$ was observed between pruning treatment and root density; the root density decreased with increased pruning treatment.

Leaf NUTRIENT ANALYSIS. This analysis was done annually for the 14 essential nutrients. There was no significant difference observed in nutrient profile for any treatment combination over the 3 years (data not shown). All the nutrients were in optimum range as per the UF IFAS
Interestingly, the fruit drop was lower in 2016 as compared with 2015; similarities in reduction of fruit drop were observed in the entire state of Florida, suggesting the weather conditions were favorable in this preharvest time period. However, in 2017, the canopy volume and fruit drop relationship was marginal. In the third year, 2017, there was no statistical difference between preharvest fruit drop for any of the pruning treatments; however, fruit drop percentage was higher as compared with previous years, most likely due to the effect of Hurricane Irma that passed over the trial location in Sept. 2017.

YIELD DATA. The harvest yields for all 3 years of the study are shown in Table 1 . In all 3 years, neither the type of fertilizer nor the $\operatorname{Pr} \times F$ was significantly different. Pruning treatment had significant effect for the first 2 years $(P<0.001$ and $P=0.022$, for 2015 and 2016, respectively). Overall, the total yield of the trees decreased with pruning treatment; however, 25\% pruning treatment yield was similar to control trees $(0 \%$ pruning) in the second year. In 2017, the yield for all pruning treatments was similar. A positive correlation was found between absolute canopy volume and yield for each year, respectively, indicating that fruit yield increases with larger canopy. Moreover, when the fruit production as pound of fruit per cubic meter of canopy $\left(\mathrm{lb} / \mathrm{m}^{3}\right)$ was compared between treatments, there were no significant differences among the treatments for any of the years (data not shown). Cumulative yield over the period of 3 years was significantly lower for $50 \%$ and $80 \%$ pruning treatment $[P<0.001$ (Fig. 4)]; a negative correlation between pruning intensity and cumulative yield was observed. In addition, a significant negative correlation between fruit drop and yield was observed for all 3 years (data not shown).

Fruit size. For the first harvest (2015) of the study, pruning treatment had a significant effect on fruit size $[P=0.025$ (Table 2)]; however, the observed differences between $0 \%$ and $25 \%$ pruning treatment were marginal. In 2015 , no interaction $(\operatorname{Pr} \times \mathrm{F})$ or effect of fertilizer was observed. Interestingly, the fruit from $80 \%$ pruning treatment were 


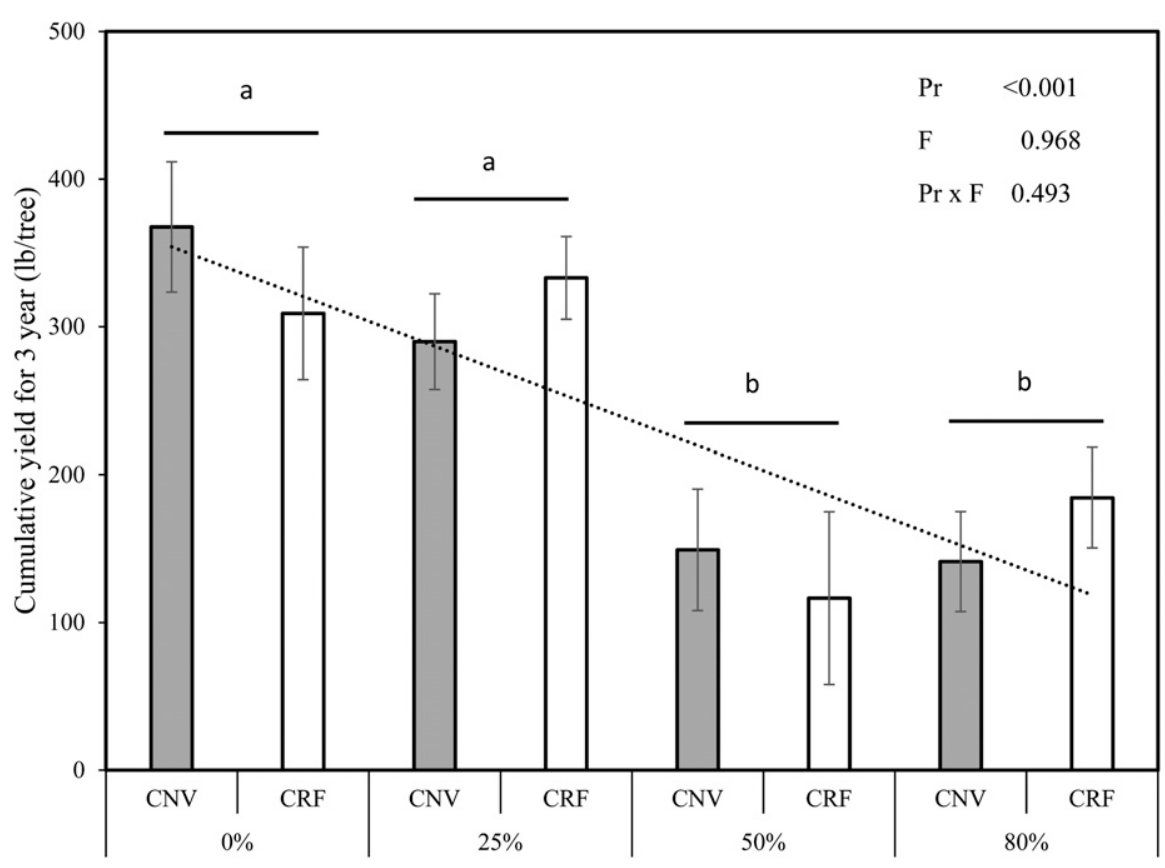

Fig. 4. Average 3-year cumulative yield with probability values in

Huanglongbing-affected 'Hamlin' sweet orange on Swingle citrumelo rootstock. The pruning was performed in Jan. 2015. The pruning treatments (Pr) were as follows: 1 ) $0 \%$, no canopy removal (control treatment) tree height $\approx 12 \mathrm{ft}$ $(3.65 \mathrm{~m}) ; 2) 25 \%$ reduction, canopy topped $\approx 9 \mathrm{ft}(2.74 \mathrm{~m}) ; 3) 50 \%$ reduction, canopy topped $\approx 6 \mathrm{ft}(1.82 \mathrm{~m})$; and 4$) 80 \%$ reduction, canopy topped at $6 \mathrm{ft}$ and all the major branches were manually cut back (buck horned). The fertilizer treatments (F) were as follows: 1 ) conventional fertilizer (CNV) applied at 200 $\mathrm{lb} /$ acre $\left(224.17 \mathrm{~kg} \cdot \mathrm{ha}^{-1}\right)$ nitrogen $(\mathrm{N})$ in five split applications per year, and 2 ) controlled-release fertilizer (CRF) applied at $150 \mathrm{lb} /$ acre $\left(168.13 \mathrm{~kg} \cdot \mathrm{ha}^{-1}\right) \mathrm{N}$ split in three applications per year. The dotted lines show the significant inverse correlation between pruning intensity and cumulative yield was observed. Bars not assigned the same letter indicate statistically significant differences among pruning treatment, given that there were no interaction effects of Pr and F, using Tukey's honestly significance difference test at $\alpha=0.05$. There was no interaction between main effects of $\operatorname{Pr}$ and F. Error bars $= \pm S D ; 1 \mathrm{lb}=0.4536 \mathrm{~kg}$.

of good size, similar to control trees ( $0 \%$ pruning), but were dry inside and the rind was puffy and uneven in texture. In 2016, the effect of fertilizer and $\operatorname{Pr} \times \mathrm{F}$ was significant $(P<0.001)$; however, the pruning treatment alone had no significant effect on fruit size $(P=$ 0.077). Across all pruning treatments, the average fruit size from CRF-treated trees (2.44 inches) was larger as compared with average fruit size from $\mathrm{CNV}$ treated trees (2.35 inches). In the last and final year, 2017, $\operatorname{Pr} \times \mathrm{F}$ interaction as well as fertilizer and pruning effect were significant $(P<0.001)$, where $\mathrm{CNV}$-treated trees in $0 \%$ and $50 \%$ pruning treatment had significantly larger fruit compared with CRF-treated 0\% and $50 \%$ pruning treatment, respectively. Overall, the average fruit size was smaller in 2017 and 2016 as compared with 2015. No consistent trend was observed for fruit size.
Soluble solids. Soluble solids content of the juice for the three harvests are presented in Table 2. In the first and second years of harvest, a significant effect of pruning treatment was observed on soluble solids content in the juice $(P<$ $0.001)$. Overall, in both years, the soluble solids content was reduced with higher pruning treatment, which was more pronounced in the first year. A significant $\operatorname{Pr} \times F$ was observed in 2015; however, no consistent pattern was observed. CNVtreated control trees ( $0 \%$ pruning) had significantly higher soluble solids content than CRF-treated control trees ( $0 \%$ pruning); the opposite trend was observed for $25 \%$ pruning treatment. In 2017, soluble solids content for all treatment combinations was similar, ranging from 9.2 to 11.1 .

\section{Discussion}

The presented 3-year study evaluated the effects of pruning and fertilizer on health and productivity of HLB-affected trees. With pruning, a significant amount of canopy was removed (especially in $50 \%$ and $80 \%$ pruning treatments) and trees were rejuvenated; however, the canopy removal (including infected leaves) did not affect the presence of bacteria. The CLas was still detectable in the leaves at 3 and 6 months after pruning. It is possible that on pruning, the roots mobilize the carbohydrates to support shoot growth (Eissenstat and Duncan, 1992) and as the roots are highly colonized with CLas (Johnson et al., 2014), the CLas was mobilized to the shoot with bulk phloem flow. Another possibility is reinfection; the new vegetative growth that emerged after pruning was still susceptible to reinfection (we observed heavy asian citrus psyllid activity on newly emerged leaves after pruning). The trees used in this study were maintained under an insecticide program, but insecticides are not always 100\% effective. Moreover, according to recent studies, the asian citrus psyllids in the citrus production region of Florida have become resistant to systemic insecticides (Langdon et al., 2018); therefore, the spread of infection is difficult to contain via vector control. Comparable to our results, Rouse et al. (2017) and Lopes et al. (2007) reported that the pruned trees showed symptomless new growth but were never detected free of CLas. Similarly, Daugherty et al. (2018) reported that the severe pruning of Pierce's disease (Xylella fastidiosa)affected grapevines (Vitis vinifera) did not affect the infection, and the symptoms of the disease reappeared within two seasons. This suggests that pruning is not an ideal strategy to suppress a systemic pathogen when the trees are grown in a disease-endemic environment.

An important aspect of this experiment was to evaluate the efficacy of pruning and CRF in rejuvenating the HLB-affected trees. A light pruning, or maintenance pruning, is a common practice in citrus production in Florida (Vashisth et al., 2017). The $25 \%$ pruning from this study can be considered equivalent to a light pruning. Fertilizer and 
Table 2. Average fruit size and soluble solids content at time of harvest with probability values in in Huanglongbing-affected 'Hamlin' sweet orange on Swingle citrumelo rootstock. The pruning was performed in Jan. 2015. The pruning treatments $(\mathrm{Pr})$ were as follows: 1 ) $0 \%$, no canopy removal (control treatment) tree height $\approx 12 \mathrm{ft}(3.65 \mathrm{~m}) ; 2) 25 \%$ reduction, canopy topped $\approx 9 \mathrm{ft}$ $(2.74 \mathrm{~m}) ; 3) 50 \%$ reduction, canopy topped $\approx 6 \mathrm{ft}(1.82 \mathrm{~m})$; and 4$) 80 \%$ reduction, canopy topped at $6 \mathrm{ft}$ and all the major branches were manually cut back (buck horned). The fertilizer treatments (F) were as follows: 1 ) conventional fertilizer (CNV) applied at $200 \mathrm{lb} /$ acre $\left(224.17 \mathrm{~kg} \cdot \mathrm{ha}^{-1}\right)$ nitrogen $(\mathrm{N})$ in five split applications per year, and 2) controlled-release fertilizer (CRF) applied at $150 \mathrm{lb} /$ acre $\left(168.13 \mathrm{~kg} \cdot \mathrm{ha}^{-1}\right) \mathrm{N}$ split in three applications per year.

\begin{tabular}{|c|c|c|c|c|c|c|c|}
\hline \multirow[b]{2}{*}{$\operatorname{Pr}(\%)$} & \multirow[b]{2}{*}{$\mathbf{F}$} & \multicolumn{3}{|c|}{ Fruit size (inches) ${ }^{\mathrm{z}}$} & \multicolumn{3}{|c|}{ Soluble solids content (\%) } \\
\hline & & 2015 & 2016 & 2017 & 2015 & 2016 & 2017 \\
\hline \multirow[t]{2}{*}{0} & $\mathrm{CNV}$ & $2.71 \mathrm{a}^{\mathrm{y}}$ & $2.36 \mathrm{ab}^{\mathrm{x}}$ & $2.51 \mathrm{a}^{\mathrm{x}}$ & $8.7 \mathrm{a}^{\mathrm{x}}$ & $10.2 \mathrm{a}^{\mathrm{y}}$ & 10.5 \\
\hline & CRF & 2.65 & $2.40 \mathrm{ab}$ & $2.37 \mathrm{~b}$ & $7.7 \mathrm{~b}$ & 10.5 & 11.0 \\
\hline \multirow[t]{2}{*}{25} & $\mathrm{CNV}$ & $2.57 \mathrm{~b}$ & $2.32 \mathrm{ab}$ & $2.35 \mathrm{c}$ & $7.9 \mathrm{~b}$ & $9.4 \mathrm{ab}$ & 10.3 \\
\hline & CRF & 2.64 & $2.36 \mathrm{ab}$ & $2.37 \mathrm{bc}$ & $8.4 \mathrm{ab}$ & 9.5 & 10.8 \\
\hline \multirow[t]{2}{*}{50} & $\mathrm{CNV}$ & $2.67 \mathrm{ab}$ & $2.34 \mathrm{ab}$ & $2.53 \mathrm{a}$ & $7.9 \mathrm{bc}$ & $10.0 \mathrm{ab}$ & 10.3 \\
\hline & CRF & 2.71 & $2.39 \mathrm{ab}$ & $2.40 \mathrm{~b}$ & $7.6 \mathrm{c}$ & 8.9 & 11.1 \\
\hline \multirow[t]{2}{*}{80} & $\mathrm{CNV}$ & $2.61 \mathrm{ab}$ & $2.29 \mathrm{~b}$ & $2.38 \mathrm{bc}$ & $6.0 \mathrm{~d}$ & $9.3 \mathrm{~b}$ & 9.2 \\
\hline & CRF & 2.72 & $2.52 \mathrm{a}$ & $2.43 \mathrm{ab}$ & $6.2 \mathrm{~d}$ & 8.3 & 10.7 \\
\hline $\operatorname{Pr}$ & & 0.025 & 0.077 & $<0.001$ & $<0.001$ & 0.026 & 0.190 \\
\hline $\mathrm{F}$ & & 0.232 & $<0.001$ & $<0.001$ & 0.383 & 0.279 & 0.002 \\
\hline $\operatorname{Pr} \times F$ & & 0.264 & 0.001 & $<0.001$ & $<0.001$ & 0.479 & 0.479 \\
\hline
\end{tabular}

${ }^{\mathrm{z}} 1$ inch $=2.54 \mathrm{~cm}$.

${ }^{y}$ Means not followed by the same letters are statistically significantly different among Pr within that year, given that there was no interaction effects of Pr and F using Tukey's honestly significance difference (HSD) test at $\alpha=0.05$. ${ }^{\mathrm{x}}$ Means not followed by the same letters are statistically significantly different among $\operatorname{Pr} \times \mathrm{F}$ treatment within that year using Tukey's HSD test at $\alpha=0.05$

pruning treatment displayed a significant interaction, with higher LAI from CRF compared with CNV only at $25 \%$ pruning level (Fig. 2). An increase in canopy density (LAI) of $25 \%$ pruned-CRF-treated trees was observed, suggesting that light pruning when combined with a constant supply of nutrition can provide vigor and capability to grow and, therefore, can be beneficial for HLB-affected trees. The use of CRF provides a constant supply of nutrients to compromised root systems and improves growth and productivity of HLB-affected trees. The use of CRF in new plantings and early years of growth has been observed to be promising for trees growing under HLB-prevalent conditions (Vashisth and Grosser, 2018). However, the LAI for the other pruning treatments did not change with the use of CRF, suggesting that the improvement in tree density cannot be solely dependent on a form of fertilizer but is a combination of a number of factors. Similar to LAI, the root density showed a comparable trend for $25 \%$ pruning treatment. The average root density in $25 \%$ pruning for $\mathrm{CNV}$ and CRF were 0.244 and $0.376 \mathrm{mg} \cdot \mathrm{cm}^{-3}$, respectively (Fig. 3). However, unlike LAI, the interaction $(\operatorname{Pr} \times \mathrm{F})$ was not significant for root density. Nonetheless, canopy and root density, when taken together, show that the use of CRF (constant supply of nutrients) can be beneficial when light pruning is part of an annual grove maintenance program. In this experiment, the root density was measured at the end of the experiment; and, even after 3 years since pruning, a significant effect of pruning was observed on the root mass. The root mass decreased with the increase in pruning intensity. Even though significant growth in canopy was observed during the 3 years, it was still not sufficient to counteract the effect of intense pruning ( $50 \%$ and $80 \%$ ) on the root and shoot system. Likewise, Rouse et al. (2017) had reported that "buck horn" pruning resulted in vigorous growth in trees; nonetheless, untreated trees had larger canopy volume and leaf area. Altogether, this suggests that high pruning treatment can have a detrimental effect on tree growth and can take years to grow to prior or improved condition, potentially making them uneconomical. HLB-affected trees go through significant root loss (Johnson et al., 2014) and canopy dieback (Bové, 2006). Therefore, it can be inferred from our results that severe pruning treatments are unfavorable for HLB-affected trees and do not generally improve yield and overall growth of the tree.

Fruit drop is a major concern in HLB-affected trees (Albrigo and Stover, 2015). The preharvest fruit drop increases as the HLB symptoms increase and canopy density decreases (Tang et al., 2019). Similarly, in this study, a negative correlation between canopy volume and fruit drop was observed for the first 2 years of the study (Table 1). In the third year, most likely due to Hurricane Irma winds, the fruit drop was higher than the previous 2 years. The effect of reduced fruiting wood (due to pruning) and high fruit drop was observed on the yield in the first year for all of the pruning treatments; however, in the second year, the effect was observed in the $50 \%$ and $80 \%$ pruning treatments and the $25 \%$ pruning treatment was similar to the $0 \%$ pruning treatment in all aspects (Table 1). Similar to fruit drop, in the third year, there were no differences in yield among different treatments. Overall, the 3-year cumulative yield was significantly low for the $50 \%$ and $80 \%$ pruning treatments, suggesting that the yield loss occurring in the first 2 years is substantial and, therefore, not economically viable (Fig. 1, Table 1). Rouse et al. (2017) also observed a significant reduction in yield following pruning, even though the trees produced the same amount of fruit as unpruned trees in subsequent years. Therefore, the loss in yield that occurred in the first year and no significant gain in yield in the following years resulted in severe pruning as an unviable strategy. Interestingly, severe pruning resulted in fruit of low quality (Table 2 ). The juice soluble solids content was significantly low for all 3 years in the $80 \%$ pruning treatment and for 2 years in the $50 \%$ pruning treatment. Iglesias et al. (2007) reported that fruit set, growth, and quality highly depend on carbohydrate availability; therefore, any kind of reduction in vegetative growth can influence the 
carbohydrate availability to fruit, consequently affecting the yield and quality. Yuan et al. (2005) reported that up to $25 \%$ defoliation close to harvest had no effect on fruit yield, quality, and canopy growth; however, $50 \%$ defoliation reduced the overall soluble solids produced per tree.

In this study, we did not observe a beneficial effect of CRF on tree growth, fruit drop, yield, and fruit quality. However, it is worth noting that $\mathrm{N}$ and other nutrients applied through CRF in this study were 25\% less than the CNV fertilizer. In addition, CRF was applied three times per year, whereas CNV was applied five times per year. Overall, with the use of CRF, the amount of nutrients, time, and money spent in fertilizer applications was reduced.

Altogether, the results obtained from this study suggest that severe pruning is not beneficial for HLBaffected trees. Severe pruning can exacerbate the canopy and root loss, fruit drop, and reduction in yield.

\section{Literature cited}

Albrigo, L.G. and E.W. Stover. 2015. Effect of plant growth regulators and fungicides on Huanglongbing-related preharvest fruit drop of citrus. HortTechnology 25:785-790.

Ananthakrishnan, G., N. Choudhary, A. Roy, V.G. Sengoda, E. Postnikova, J.S. Hartung, A.L. Stone, V.D. Damsteegt, W.L. Schneider, J.E. Munyaneza, and R.H. Brlansky. 2013. Development of primers and probes for genus and species specific detection of 'Candidatus Liberibacter species' by real-time PCR. Plant Dis. 97:1235-1243.

Bassanezi, R.B., L.H. Montesino, M.C. Gasparoto, A. Bergamin Filho, and L. Amorim. 2011. Yield loss caused by Huanglongbing in different sweet orange cultivars in São Paulo, Brazil. Eur. J. Plant Pathol. 130:577-586.

Bové, J.M. 2006. Huanglongbing: A destructive, newly-emerging, century-old disease of citrus. J. Plant Pathol. 8:7-37.

Daugherty, M.P., R.P. Almeida, R.J. Smith, E.A. Weber, and A.H. Purcell. 2018. Severe pruning of infected grapevines has limited efficacy for managing pierce's disease. Amer. J. Enol. Viticult. 69:289-294.

Eissenstat, D.M. and L.W. Duncan. 1992. Root growth and carbohydrate responses in bearing citrus trees following partial canopy removal. Tree Physiol. 10:245-257.

Etxeberria, E., P. Gonzalez, D. Achor, and G. Albrigo. 2009. Anatomical distribution of abnormally high levels of starch in HLBaffected Valencia orange trees. Physiol. Mol. Plant Phytopathol. 74:76-83.

Graham, J. 1995. Root regeneration and tolerance of citrus rootstocks to root-rot caused by Phytophthora nicotianae. Phytopathology 85:111-117.

Graham, J., E. Johnson, T. Gottwald, and M. Irey. 2013. Presymptomatic fibrous root decline in citrus trees caused by Huanglongbing and potential interaction with Phytophthora spp. Plant Dis. 97:1195-1199.

Halbert, S.E. and K.L. Manjunath. 2004. Asian citrus psyllids (Sternorrhyncha: Psyllidae) and greening disease of citrus: A literature review and assessment of risk in Florida. Fla. Entomol. 1:330-353.

Iglesias, D.J., M. Cercós, J.M. ColmeneroFlores, M.A. Naranjo, G. Ríos, E. Carrera, O. Ruiz-Rivero, I. Lliso, R. Morillon, F.R. Tadeo, and M. Talon. 2007. Physiology of citrus fruiting. Braz. J. Plant Physiol. 4:333-362.

Johnson, E.G., J. Wu, D.B. Bright, and J.H. Graham. 2014. Association of 'Candidatus Liberibacter asiaticus' root infection, but not phloem plugging with root loss on Huanglongbing affected trees prior to appearance of foliar symptoms. Plant Pathol. 63:290-298.

Kadyampakeni, D.M., K.T. Morgan, A.W. Schumann, and P. Nkedi-Kizza. 2014. Effect of irrigation pattern and timing on root density of young citrus trees infected with Huanglongbing disease. HortTechnology 24:209-221.

Kim, J.S., U.S. Sagaram, J.K. Burns, J.L. $\mathrm{Li}$, and N. Wang. 2009. Response of sweet orange (Citrus sinensis) to 'Candidatus Liberibacter asiaticus' infection: Microscopy and microarray analyses. Phytopathology 99:50-57.

Langdon, K.W., R. Schumann, L.L. Stelinski, and M.E. Rogers. 2018. Influence of tree size and application rate on expression of thiamethoxam in citrus and its efficacy against Diaphorina citri (Hemiptera: Liviidae). J. Econ. Entomol. 111:770-779.

Li, W., J.S. Hartung, and L. Levy. 2006. Quantitative real-time PCR for detection and identification of Candidatus Liberibacter speices associated with citrus Huanglongbing. J. Microbiol. Methods 66:104-115.

Lopes, S.A., G.F. Frare, P.T. Yamamoto, A.J. Ayres, and J.C. Barbosa. 2007. Ineffectiveness of pruning to control citrus
Huanglongbing caused by Candidatus Liberibacter americanus. Eur. J. Plant Pathol. 119:463-468.

Morgan, K.T., R.E. Rouse, and R.C. Ebel. 2016. Foliar applications of essential nutrients on growth and yield of 'Valencia' sweet orange infected with Huanglongbing. HortScience 51:1482-1493.

Obreza, T.A. and K.T. Morgan. 2008. Nutrition of Florida citrus trees. Univ. Florida, Inst. Food Agr. Sci. Ext. SL253. 16 Aug. 2019. <https://edis.ifas.ufl. $\mathrm{edu} / \mathrm{ss} 478>$.

Rouse, R.E., M. Ozores-Hampton, F.M. Roka, and P. Roberts. 2017. Rehabilitation of Huanglongbing-affected citrus trees using severe pruning and enhanced foliar nutritional treatments. HortScience 52:972-978.

Schneider, H. 1968. Anatomy of greeningdiseased sweet orange shoots. Phytopathology 58:1155-1160.

Schumann, A., K. Hostler, L. Waldo, and K. Mann. 2012. Advanced production systems for Florida citrus: Research update, Huanglongbing impacts and production forecasts. Citrus Ind. 93(8):6-12.

Spann, T.M. and A.W. Schumann. 2009. The role of plant nutrients in disease development with emphasis on citrus and Huanglongbing. Proc. Florida State Hort. Soc. 122:169-171.

Tang, L., S. Chhajed, and T. Vashisth. 2019. Preharvest fruit drop in Huanglongbing-affected 'Valencia' sweet orange. J. Amer. Soc. Hort. Sci. 144:107-117.

U.S. Department of Agriculture. 2018. Florida citrus statistics 2017/2018. 16 Aug. 2019. <https://www.nass.usda.gov/ Statistics_by_State/Florida/Publications / Citrus/index.php $>$.

Vashisth, T., M. Zekri, and F.M. Alferez. 2017. Canopy management, p. 65-67. In: L. Diepenbrock, M.M. Dewdney, and T. Vashisth (eds.). 2018-2019 Florida citrus production guide. Coop. Ext. Serv., Univ. Florida, Inst. Food. Agr. Sci. Gainesville.

Vashisth, T. and J. Grosser. 2018. Comparison of controlled release fertilizer (CRF) for newly planted sweet orange trees under Huanglongbing prevalent conditions. J. Hort. 5:244-249.

Vashisth, T. and C. Vincent. 2018. Living with yellow dragon disease. Citrus Ind. 99(3):10-13.

Yuan, R., F. Alferez, I. Kostenyuk, S. Singh, J.P. Syvertsen, and J.K. Burns. 2005. Partial defoliation can decrease average leaf size but has little effect on orange tree growth, fruit yield and juice quality. HortScience 40:2011-2015. 